This is the author's final, peer-reviewed manuscript as accepted for publication. The publisher-formatted version may be available through the publisher's web site or your institution's library.

\title{
The Millennial graduate student: implications for educators in the fashion discipline
}

Joy Kozar \& Kim Hiller Connell

\section{How to cite this manuscript}

If you make reference to this version of the manuscript, use the following information:

Kozar, J., \& Hiller Connell, K. (2013). The Millennial graduate student: Implications for educators in the fashion discipline. Retrieved from http://krex.ksu.edu

\section{Published Version Information}

Citation: Kozar, J., \& Hiller Connell, K. (2013). The Millennial graduate student: Implications for educators in the fashion discipline. International Journal of Fashion Design, Technology and Education, 6(3), 149-159.

Copyright: ( 2013 Taylor \& Francis

Digital Object Identifier (DOI): doi:10.1080/17543266.2013.795611

Publisher's Link:

http://www.tandfonline.com/doi/full/10.1080/17543266.2013.795611\#.Utml69Lnbcs

This item was retrieved from the K-State Research Exchange (K-REx), the institutional repository of Kansas State University. K-REx is available at http://krex.ksu.edu 


\title{
The Millennial Graduate Student: Implications for Educators in the Fashion Discipline
}

\author{
Abstract \\ The purpose of this study was to expand upon an overall understanding of today's Millennial \\ graduate student. Information related to the motivations of Millennial generation students in \\ pursuing master’s degrees in fashion programs were collected, in addition to analysing the \\ expectations of Millennial students while in graduate programs. Participants included both \\ master's-level graduate students enrolled in fashion programs and graduate faculty at the \\ students' home institutions. The similarities and expectations among students and faculty were \\ identified. A major finding was that Millennial graduate students are primarily motivated by \\ industry-related career goals, and do not perceive conducting empirical research as central to \\ their education. The educational implications for graduate faculty based on the findings of this \\ study are addressed, noting areas of educational reform and additional research. \\ Key Words: Fashion programs, Graduate studies, Master’s degree, Millennials
}




\section{Introduction}

In recent years, faculty in fashion programs have observed a transformation in the aptitudes and attitudes of students applying for and pursuing graduate degrees and the emergence of a new type of student—-the Millennial Generation graduate student (Hiller Connell and Kozar 2011). In response, the purpose of this study was to expand upon the understanding of fashion graduate students who are members of the Millennial cohort by examining: 1) their motivations for going to graduate school, and 2) their expectations of graduate education and their interaction with faculty and administrators. This information is valuable for fashion graduate programs throughout the United States and internationally, as faculty and administrators develop and refine existing graduate curriculums, policies, and procedures. In order to foster sustainable admittance and retention rates, it is also necessary to respond effectively to the characteristics of the new generation of students, while developing and sustaining best practices for supporting students'

goals of completing graduate degrees. According to a report published by the Association of American Universities (AAU) Committee on Graduate Education (1998), student interests should be an integral part in designing graduate curriculums. As part of their postsecondary education, students should be enriched in their thinking, prepared for a variety of careers, and equipped with the skills and abilities that will contribute to their success in a diverse and global workplace. Similarly, Wendler et al. noted that graduate education must focus on the 'application of knowledge and skills in creative and innovative ways that will help ensure our country’s [U.S.] future economic prosperity, influence social growth, and maintain our leadership position in the global economy’ (2010, p. 1).

The nature of this study is centered on identifying Millennial students' academic expectations and motivations in seeking an advanced education. Given recent trends in academia, 
such as the consolidation or elimination of programs and increasing tuition rate, this study is both timely and relevant. As reported by Wendler et al. (2010), graduate education in the United States is facing heightened competition as other countries like China and India heavily invest in their postsecondary educational systems and are experiencing increased reputation of their graduate programs. Additionally, attrition has been identified as a substantial challenge facing graduate programs. In examining reasons for leaving graduate school, program dissatisfaction was the third most cited reason among U.S. graduate students (Wendler et al. 2010).

The findings of this study are also valuable to university faculty and administrators who predominately represent the Baby Boomer and Generation X cohorts, by understanding differences in personality characteristics, perceptions of educational outcomes, and work ethic and styles between Millennials and older generations. Fashion-related graduate programs can use this information to recruit and graduate talented Millennial students.

\section{Review of Literature}

Generational theory states that individuals born during designated time periods share similar experiences which shape their attitudes, beliefs, and behaviours. Historical events that occur in adolescence and young adulthood are of particular importance (Schuman and Scott 1989). According to Mannheim:

...belonging to the same generation or age group, endow[s] the individuals sharing in [it] with a common location in the social and historical process, and thereby limit them to a specific range of potential experiences, predisposing them for a certain characteristic mode of thought and experience, and a characteristic type of historically relevant action (1952, p. 291).

\subsection{Characteristics of the Millennial Generation}


The Millennial generation is a cohort of individuals born between the years 1979 and 1994 (Schiffman and Kanuk 2010). As with any generation, Millennials are characterized as possessing both positive and negative attributes. Typically, Millennials are illustrated as being optimistic, team- and goal-oriented, achievement driven, and self-assured (Donnison 2010, Howe and Strauss 2003, Oblinger 2003). Additional core personality traits of Millennials include sheltered, confident, conventional, and pressured (Strauss and Howe 2000). Millennials are also regarded as self-centered, unmotivated, disrespectful, and disloyal (Howe and Strauss 2003, Myers and Sadaghiani 2010); in fact, Millennials are characterized as significantly more narcissistic than older generations (Twenge et al. 2008).

Related to the sense among Millennials that they are special, Strauss and Howe (2000) note that this is reflective of growing up in a society that highly valued them and encouraged them to always feel good about themselves. Millennial students were reared during the "no child left behind” educational and societal approach (Howe and Strauss 2003). The result of this is a generation that has an inflated view of their worth, limited patience for individuals who challenge this attitude, and trouble overcoming problems (Donnison 2010, Howe and Strauss 2003, Taylor 2006). Millennials have been sheltered from society’s dangers (Strauss and Howe 2000). McGlynn (2008) noted that Millennials can be difficult to reach and motivate. Parents of Millennials nurtured their children's self-esteem and as a result, Millennials tend to be resistant to feedback that questions their abilities or challenges their skills. Donnison (2010) reported similar characteristics — while Millennials are ambitious, success-oriented, and goal-achieving; they also have an inflated confidence that they are valuable.

Taylor (2006) indicated that Millennials have difficulty successfully entering the workforce; Millennials find long-term thinking challenging and are often perplexed in handling 
detail-specific tasks. Millennials do not like delaying gratification and prefer to keep their options open as opposed to making long-term commitments (Mackay 1997). Since Millennials believe that their academic and intellectual abilities are above average, they overrate their employability, desirability, and skills, which then sets a precedent for unrealistic expectations (Donnison 2010). As stated by Donnison, "Millennials believe that they deserve to have their voices heard and their demands met” (pg. 6). Further, as noted by DeBard (2004), while Millennials are ambitious in their pursuits, they have difficulty in long-term reasoning. Because they have been sheltered and have relied upon authorities to make decisions, they have difficulty in college when required to be more self-directed. The common perception among older generations is that Millennials have grown up in 'good times,' experiencing relatively comfortable lifestyles (Myers and Sadaghiani 2010). Taylor (2006) described Millennials' childhoods as 'sanitized.'

\subsection{Characteristics of Millennials versus Boomers and Xers}

Millennials are the offspring of Baby Boomers (born between the years 1946-1964); and, as a result, Boomers and Millennials are often perceived as compatible in their characteristics and values. Baby Boomers, who consider their Millennial children the 'next great generation' (DeBard 2004, Donnison 2010), have 'cocooned’ their children with child-oriented legislations, polices, and rearing practices. Boomers are viewed as confident, authoritative, and motivated by title and recognition from others in approaching their work (DeBard 2004). Drawing from the generation theoretical descriptions recorded by Strauss and Howe (1991) and Howe and Strauss (2000), Kowske et al. (2010) defined Boomers as:

Much heralded but failing to meet expectations, smug, self-absorbed, intellectually arrogant, socially mature, culturally wise, critical thinkers, spiritual, religious, having an 
inner fervor, radical, controversial, non-conformist, self-confident, self-indulgent (p. 267).

Given the likenesses between Boomers and Millennials, it may actually be individuals within the Generation X cohort (born between the years 1965-1978) ${ }^{1}$ that perceive the greatest sense of stress and/or vexation in effectively working with and directing Millennials. Gen Xers, described by generational theorists as distant, doubtful, and seeking freedom and independence in their work (DeBard 2004), tend to possess qualities such as:

Cynical, distrusting, bearing the weight of the world, fearful, lost, wasted, incorrigible, in-your-face, frenetic, shocking, uneducated, shallow, uncivil, mature for their age, pragmatic, apathetic and disengaged politically, independent, self-reliant, fatalistic, mocking, under-achieving (Kowske et al. 2010, p. 267).

DeBard (2004) noted that, compared to Generation Xers, Boomers are much more obliging in nurturing Millennial students’ self-esteem. Millennials general sense of optimism and ambition can be provoking to Gen Xers, who feel that they have assumed greater effort in achieving educational and career goals, while being expected to perform at higher standards of rigor and accountability. Further, Gen Xers may be frustrated by Millennials who view their supervisors as 'workplace parents’ (Alsop 2008).

Because many Millennials have lived protected lives, they crave community, need feedback and/or reassurance, and expect accolades for activities in which they are involved in (despite actual performance outcomes related to those activities). As noted by several researchers, Millennials face significant difficulty in being self-directed. They are close to their parents (who are typically Boomers), and opposite that of Gen Xers, Millennials rely on

\footnotetext{
${ }^{1}$ The year of transition between the Generation X cohort and Millennials varies slightly according to the source. This study uses the dates published by Schiffman and Kanuk 2010.
} 
authority to guide behaviour and make decisions (DeBard 2004, Meriac et al. 2010, Schneider and Stevenson 1999). Gen Xers typically maintain a low level of trust or reliance on authority. As far as family life is concerned, while Boomers were indulged as children and Millennials were protected as children, Gen Xers were alienated as children (or otherwise referred to as the ‘latchkey generation’) (DeBard 2004).

Boomers viewed their education as providing freedom of expression, whereas Millennials want classroom expectations to be clearly outlined. In both educational and work-related settings, Millennials seek regular and open communication and feedback from instructors and/or supervisors (Myers and Sadaghiani 2010). According to Martin (2005), more so than previous cohorts, Millennials entering the workforce need continual communication and dialogue with those representing an authoritative role. Opposite to that, Gen Xers approached their education in a 'no-nonsense, matter-of fact' fashion. And, while Millennials crave community, Gen Xers seek individuality and are often apathetic towards the 'greater good' (DeBard 2004).

Meriac et al. (2010) described significant differences between the three generational cohorts, including characteristics related to work ethic. Boomers report the highest levels of work ethic, including self-reliance, morality/ethics, hard work, centrality of work, and delay of gratification. Boomers are often characterized as 'workaholics,' critical of those that do not mimic these same behaviours (McGuire et al. 2007). On the other hand, Gen Xers loath group work, meetings, and maintain a desire to work autonomously and individually (Howe and Strauss 2003, Martin 2005). Among the three cohorts, Millennials have the strongest desire to maintain a balance between work and family/social life and maintain a level of conformity and conventionality (Howe and Strauss 2003, Ott et al. 2008). 
In examining Millennials’ organizational relationships and performance as compared to older generations, Myers and Sadaghiani noted, 'Their differing experiences and values can affect their perspectives, their evaluation of co-workers, and their organizational expectations' (2010, p. 227). This same logic should be applied to academic settings. When individuals do not meet the expectations for appropriate behaviour as perceived by individuals representing other cohorts, acceptance, interaction, attitudes and behaviours can be stifled and/or hindered.

\subsection{Educational Implications}

Overall, Millennials' learning preferences include teamwork, the integration of technology, and hands-on experiences. Many researchers have noted the collaborative, teambased mentality of Millennial students, which could pose problematic for those pursuing an advanced education that typically requires a significant level of individual work. As noted previously, a defining characteristic of Millennials is their struggle to be self-directed.

According to Strauss and Howe (2000), teamwork is highly valued among Millennials and is reflective of their preponderance to be team- and goal-oriented. However, Strauss and Howe (2000) suggest that this team-based mentality provides a fail proof net for avoiding failure. This finding complements those noted by Alsop (2008), who described Millennials as having an 'excessive' reliance on team-based direction and decision making. By working in teams, Millennials have delayed their individual, critical-thinking abilities and avoided the risk of making independent decisions. As stated by Myers and Sadaghiani, 'a group-reliant mentality does not foster individual decision-making confidence, nor does it enable individuals to demonstrate their own creativity and ability' (2010, p. 230). McGlynn (2005) reported that Millennials are heavily dependent on their peers for completing class projects and assignments 
and rely on parents for emotional support and advice. Levine (2005) remarked that Millennials are unable to think and strategize long-term, handle details, or delay gratification.

Millennials also have a need for achievement and feel pressured to perform. Unlike Generation Xers, Millennials are more apprehensive about making mistakes and doubt their abilities (Howe and Strauss 2003). However, because Millennials come from a highly structured background with set standards, they anticipate high grades as a reward (DeBard 2004). Millennials expect educators to organize and lead them on a path to success.

In educating Millennials, Howe and Strauss (2003) noted that feedback and structure are critical. Millennials tend to expect that very narrow parameters will be set in completing coursework and will only do what is expected of them given educational objectives (Sax 2003). Millennials have high expectations for their education and they expect good grades for meeting minimum expectations. According to Howe and Strauss, Millennials believe that they will receive preferential treatment if they ask for it. Moreover, faculty can expect Millennials to complain about grades or mistreatment perceived as unfair or inequitable and to be preoccupied on their performance as it relates to getting an 'A.' As noted previously, Millennials have a tendency to resist those who challenge their skills and abilities. Millennial students expect all aspects of their educational experiences to be 'team-based,' including team teaching, group assignments and grading. Millennials perceive their education as a product to purchase, rather than as a learning process (McGlynn 2008), approaching their schooling with a consumer mentality; that excellent grades should be obtained by having paid for the credits (Taylor 2006). Engagement in the educational experience is essential to motivating Millennial students and improving retention rates. Taylor (2006) noted that Millennials, as students, can be disengaged, complacent, and entitled. McGlynn (2008) reported Millennials as expecting instant 
gratification, anticipating 24/7 feedback from faculty and administrators. Because Millennials have been encouraged to follow rules, they anticipate that policies and procedures will be effectively communicated in a structured way (Martin and Tulgan 2001). Consequently, researchers recommend to educators to have very coordinated and well-defined syllabi and student handbooks (DeBard 2004, Wilson and Gerber 2008). Moreover, as college students, when Millennials encounter difficulties, they presume unlimited institutional resources are owed them (McGlynn 2008).

Information reported by Taylor (2006) should be of particular importance to graduate educators. As part of his paper on 'Generation NeXt Comes to College,' the author describes Millennials as expecting 'good' grades for minimal effort and/or receiving high marks/course credit based entirely on attendance. Moreover, Taylor noted Millennials overall naivety about the future and the discrepancy between their inefficiencies/inabilities and expectations regarding success in academia and the workplace, 'That these students are a poor fit for traditional academic activities and expectations is an understatement' (2006, p. 249).

Taylor (2006) also notes the technological orientation of today's students. Compared to Boomers and Gen Xers, Millennials are the most technological savvy. However, because of their unlimited access to information found online, Millennials often have difficulty in discerning legitimate sources of information. As noted by previous authors, academic honesty is an issue that needs to be addressed in educating Millennials (DeBard 2004, Newton 2000). Given the breadth and infinite access to information on the Internet, Millennials have a blurred sense and/or overall misunderstanding of what constitutes plagiarism. Moreover, because of perceived pressures to succeed, Howe and Strauss (2003) document the necessity for helping Millennials understand the constructs of cheating. As discussed by DeBard (2004), rules regarding academic 
honestly should be clearly explained to Millennial students. Holliday and Li (2004) reported that Millennial students have extensive experience using the Internet as a primary source of information but have little knowledge of how information is produced, organized, and disseminated. As students, Millennials tend to focus on the information they find first and perceive it as sufficient, motivated by speed and convenience, stopping at the first answer they find. Millennials need to be taught techniques for gathering information through appropriate sources. Because Millennials perceive digital technologies as fundamental to their lives, behaviours, and personalities (Donnison 2010), they have a sense of immediacy/urgency, short attention span, and predisposition to boredom (Pekala 2001). Taylor (2006) recommends that educators embrace technology in academic activities.

Other challenges in educating Millennials include their increasing optimism about their ability to succeed in college. Horn et al. (2003) noted the results of a National Household Education Program survey which reported that among approximately 7,900 students from sixth to twelfth grade, $94 \%$ of participants said they had plans to attend college; interestingly, $96 \%$ of the children's parents responded yes to the question 'Do you think your children will attend college?.' Yet, Millennials spend less time studying as compared to previous generations. Millennials often work outside the university setting and overall, are less committed to their overall educational endeavours (Sax 2003). Of particular concern among educators should be a finding by Schneider and Stevenson (1999), who suggested that Millennials may have unrealistic expectations of effort needed to be academically and professionally successful. Overall, Millennials are found to be unprepared for the rigors of post-secondary education, including the skills and abilities needed for analytical reading, quantitative reasoning, application of knowledge, and scientific literacy (Wilson and Gerber 2008). 


\subsection{Purpose and Research Questions}

Based on the above literature and taking into consideration a majority of educationrelated research on Millennials focuses on undergraduate students, the purpose of this study was to expand upon the understanding of graduate students who are members of the Millennial generation, particularly those within the fashion discipline. The study included an examination of Millennial students' motivation for going to graduate school and the expectations they have of a graduate education. This information is valuable for fashion-related graduate programs as they seek to develop graduate curriculum responsive to the characteristics of the new generation of students. Therefore, the research questions examined in this study included:

1. What are the factors motivating Millennial generation students to pursue master's degrees in fashion-related programs?

2. What expectations do Millennial generation master's degree students in the fashion discipline have of a graduate education?

3. How do the expectations of the students differ from those of graduate faculty?

\section{Method}

This study was intended to be exploratory in nature and utilized survey research techniques. To the authors' knowledge, no scales exist in current literature that measures the intended outcomes of this study. Therefore, this study is the first step in characterizing Millennial graduate students within the fashion discipline.

An open-ended questionnaire, developed as an online survey and containing eight openended questions, was designed to understand participants' motivations for pursing a graduate degree as well as attitudes and expectations about graduate school. Examples of questions included: 'What are your reasons for pursuing a master's degree in the fashion discipline?'; 
'What do you expect to learn through your program of study as a Master's student?'; and 'What do you think you want to do after finishing your master's degree?'

Participants included master's-level graduate students enrolled in fashion programs throughout the United States as well as graduate faculty. To ensure confidentiality of participants, throughout this manuscript no university names are used and all participants are referenced with an identification code (GS refers to Graduate Student and GF refers to Graduate Faculty).

Data were first collected from graduate students. Utilizing the website of the International Textile and Apparel Association, the researchers identified 28 universities in the United States with fashion-related master's degree programs and emailed the graduate program directors at these institutions. The email included a URL link to the online survey and requested that the graduate directors forward the email to master's students currently enrolled in their programs. The questionnaire was accessible to the master's students for one month.

Altogether, 34 master's students, from 11 different institutions, completed the questionnaire (see Table 1). Among the participants' institutions, seven offered Ph.D. programs (three of which offered a College Ph.D. with a specialization in the fashion discipline). Nine institutions offered M.S. programs with a thesis option, five institutions offered an M.S. coursework only option (two of which are distance only programs), and two institutions offered an M.S. with design project option. Five institutions offered an M.A. degree; among these institutions, all but one offered a coursework only option. The options available at one institution could not be determined.

Eight of the respondents were born before 1979; consequently, given the parameters of this study, further analysis excluded these responses. The final sample included 26 participants. 
Ten participants stated their goal was to pursue a Ph.D. upon completion of the Master's; the remaining 16 respondents planned to work in the fashion industry after their Master's program. An analysis of the demographic variables revealed that a majority of the sample (88.5\%) were female and ranged in age from 21 to 32 years, with the average age being 25.3 years. Approximately 58\% of students were in at least their second semester of their master's degree, with the remaining $42 \%$ of participants in their first semester. A majority of the students (77\%) completed their undergraduate degrees in fashion-related programs and $58 \%$ of the students applied exclusively to the institution they currently attended.

\section{Insert Table 1 Here}

In the second round of data collection, through university webpages, the researchers identified the graduate faculty within the fashion programs at each of the 11 institutions represented by the graduate student participants. The faculty were emailed an invitation to participate in the study, along with a link to an online questionnaire. The questionnaire was similar to the one completed by the graduate students but the questions were rewritten to solicit faculty perceptions on graduate education. A total of 10 open-ended questions were included, such as: 'What do you perceive motivates students to apply to and complete the requirements of the master's degree in your program?'; 'What do you expect students to learn while completing the requirements of the master's program at your institution?'; and 'What career opportunities do graduates of your master's program typically pursue? Is it your perception that your master's students plan to pursue a Ph.D.?' This survey was also available for a period of one month.

Altogether, 17 faculty members from seven different universities completed the questionnaire. Faculty participants held the ranks of Department Head and/or Professor $(n=7)$, 
Associate Professor $(n=3)$, and Assistant Professor $(n=4)$, and ranged from one year to 32 years in their current position. Three faculty members did not indicate their rank or years in current position.

Upon completion of data collection, the researchers independently read and reviewed the participants' responses several times for in-depth understanding. Using elements of

phenomenological analysis (Creswell 2007, Smith et al. 2009), the researchers highlighted and made notes regarding themes emerging in the data. The authors then exchanged notes and discussed and negotiated themes. After final themes were identified, the researchers coded the data according to the themes. Through this process, the researchers inductively identified the motivations and expectations of the graduate students and faculty, remaining open to unanticipated discoveries and controlled for personal biases (Lincoln and Guba 1999).

The validity of this study was established according to strategies laid out in Maxwell (2005). First, the use of an open-ended survey allowed the researchers to capture the verbatim words of the respondents which resulted in rich representative data. Second, the researchers continuously reviewed the data for discrepant evidence and when present, presented this evidence in the study.

\section{Results}

\subsection{Motivational Factors of Millennial Graduate Students}

From the responses of the participants, three different categories classified the motivations of the participants for pursing a master's degree: (1) preparation for a career in the fashion industry, (2) educational groundwork for a doctoral degree, and (3) limited job opportunities because of the economic recession. The primary motivator for most of the participants was preparation for their career. 
After completing their degree, $62 \%$ of the participants planned on pursing employment in the fashion industry and believed they needed further education to prepare for these goals. Some of these individuals already had fashion-related undergraduate degrees but desired a greater breadth and depth of knowledge. As GS5 explained, “I received my bachelor’s in Fashion Merchandising and minored in History. Because I was really interested in fashion and historic costume I wanted to have a master’s concentration in historic textiles and costume.” Likewise, GS12 stated, "I want to further my understanding of fibre chemistry, find new potential applications of fibre chemistry to the apparel industry, and advance my career opportunities by obtaining a graduate degree.”

Other participants were shifting focus in their graduate studies and had not earned fashion-related undergraduate degrees. For example, GS26 stated that she wanted to pursue graduate studies in AT, "To gain a better understanding of certain areas of the market that I was not educated in originally and to explore other areas of thought in relation to apparel and textiles.”

A smaller portion of the respondents (38\%) intended to apply to doctoral programs after completing their master’s degrees. GS2 was one student who did want to eventually earn a doctoral degree, “I am currently pursing my master’s degree in the apparel and textiles discipline in hopes of continuing my education and obtaining a Ph.D. so I can one day teach within the AT discipline.” A similar sentiment was expressed by GS24: "I have been working in the fashion industry for the past nine years. I came to a crossroad in my life where I wanted to go back to school with the goal of eventually becoming a professor in apparel and textiles.”

In addition to the above motivations for attending graduate school, four of the participants attributed the economy and limited job opportunities as their primary motivation in 
pursuing a Master’s degree. As GS6 expressed, "I feel as if with such a difficult economy, a master’s degree might be what sets me apart.” In the same manner, GS10 said, "At the time of deciding whether or not I should get a Master's, it was difficult to find a job and I figured I might as well go get my Master’s now as opposed to settling for a job I wasn’t fond of.”

\subsection{Faculty Perceptions of Motivational Factors of Millennial Graduate Students}

When the graduate faculty were asked what they believed current Millennial students' primary motivators for pursuing graduate studies were, interesting similarities and differences emerged in comparison to the graduate student answers. Similar to the graduate student participants, the faculty recognized that many Millennial students engage in graduate studies as a way for them to achieve career goals within the fashion industry. Along these lines, GF15 stated: “Others [of our master's students] are interested in gaining additional education, hoping it will set them apart from the multitude of baccalaureate candidates for industry related jobs.” A majority of the faculty, such as GF2, also believed interests in pursuing careers in academia motivated the students: "Some are interested in becoming a faculty member and come because the master's is the first step toward that goal."

There was also congruence between the Millennial students and faculty that some students were staying in school and completing advanced degrees because of the realities of the current economic climate and difficulties in securing employment. As GF5 stated: “The job market isn’t good and they see a master's degree as something to do.”

However, the faculty also believed that some Millennial graduate students elect to enter graduate school because of a lack of direction and not knowing what else to do-a reason that was not cited by any graduate student participants. For example, GF2 believed: "Some sort of drift into graduate school...maybe because they're used to being in college and don't want to 
leave...some are still exploring.” Likewise, as stated by GF15: "I would say that some applicants are delaying entry in the "real world" and postponing the responsibility of starting a career in uncertain times, or perhaps just wanting to hang on to the joys of being a student for a couple more years.”

The faculty also attributed some of the Millennial students being motivated for graduate studies by a 'love of learning.' As proposed by GF1: “They like the academic world, love learning, and like school in general and are thus drawn to continuing their education.” Other faculty made similar comments, such as GF6:

GF6: They have a passion for knowledge. They like learning new information. They have been successful as students; they enjoy research; they enjoy reading and writing; they like to think and figure things out; they like working with others on developing new knowledge; they enjoy the content area and have a passion for the field.

This was a particularly interesting perception among the graduate faculty since it was a motivation not mentioned by any of the Millennial graduate student participants; the students were more focused on how the graduate degree would help them in attaining career goals.

\subsection{Expectations of Millennial Graduate Students}

In terms of what the Millennial graduate students expected to learn through their program of study, three themes emerged: (1) research skills, (2) content specific knowledge and skills, and (3) strategies for being competitive in the fashion industry.

Only six of the graduate student participants stated that they expected to learn more about the research process as a master's student. For example, GS4 commented: "I expect to learn how to do research and lay the foundation for my PhD.” Similarly, GS21 responded: "I expect to learn and develop my research skills.” 
Since a primary purpose of graduate studies is research and the development of new knowledge, it was surprising that more students did not state learning about the research process to be a primary expectation for their master's program of study. This is especially true among those planning to pursue a Ph.D. after completion of their Master's program $(n=10)$. Only three of these participants expected to develop their research skills as part of the Master's program.

On the other hand, a majority of the participants (73\%) anticipated that their master's degree would provide them with content specific knowledge—a learning outcome that was frequently emphasized. This finding was based on the responses received from 11 participants who planned to work in the industry upon completion of the Master's degree, as well as all but one of the participants whose goals were to pursue a Ph.D. As explained by GS17: "I expect more in depth knowledge of product development and merchandising." GS18 reported: "I expect to build on the strong foundation that I received in [my undergraduate degree in] fashion merchandising. I hope to learn how to better connect with current customers and appeal to new ones.”

Additionally, a small number of the participants $(n=4)$ expressed their expectation that their program of study would provide them with strategies for attaining a competitive advantage within the fashion industry. All of these participants were among those that stated plans for working in the industry upon completion of their Master's program, including GS11:

I expect to learn some insider tricks...how to work in the field I want and to have not just the education but also some experience to back up my knowledge of the field and hopefully learn how to apply for positions for which I am qualified.

Furthermore, when asked their perceptions of the differences between undergraduate- and graduate-level courses, the participants consistently expressed the differences in terms of the 
graduate-level courses being more difficult and having more reading, writing, and research. This finding is consistent among the entire sample. Variations in responses did not exist between those planning to pursue a Ph.D. as compared to those whose goal was to work in the industry.

The Millennial students participating in this study seemed to lack comprehension of why variances between undergraduate and graduate courses exist. There was no indication in the responses that graduate school, by demanding a greater degree of critical analysis, intends to develop a higher level of thinking and knowledge in graduate students. Few participants indicated an understanding that the intention of graduate school is a culminating experience of deeper insight and contributions towards a body of knowledge focused on a specific topic. Only two of the participants who planned to pursue a Ph.D. showed an awareness of the need to develop critical thinking and analytical skills during a Master’s program.

The study also asked the participants how their expectations for their interactions with professors differed compared to when they were undergraduate students. Responses revealed that Millennials see the faculty_-graduate student relationship as being very one-sided, with the expectation that faculty are to provide intense mentoring and guidance to graduate students. None of the respondents discussed the relationship as being reciprocal in nature or how they, as a graduate student, could contribute to faculty research programs.

\subsection{Differences in Expectations between Millennial Students and Faculty}

When asked, 'What do you expect students to learn while completing the requirements of the master's program?' faculty stated: 1) the research and/or design process, and 2) depth in knowledge. However, compared to the graduate students, the faculty consistently stated that learning the research process was an expected outcome of their master's programs—with 100\% 
of the responses reflecting expectations similar to GF1: "To master the process of research-based inquiry and developing a design concept to a problem, then creating possible design solutions.”

The faculty also expressed a belief that a purpose of the master's degree was further development of students' knowledge in a specific content area. For example, GF8 stated that an expectation of the graduate program at her school was for students to gain: "Knowledge about fibres and fabrics as they apply to conservation and quality control.” GF6 said: "I expect they will learn depth in content beyond undergraduate survey courses.”

Different from the graduate students, the faculty asserted their expectations that master's students would learn teaching, communication, and critical thinking skills. Stated by GF14:

I believe our master's is a research degree and should focus on theory and broadening a student's field of knowledge, analytical and writing skills, as well as their knowledge within certain fields. I do not believe it is a vocational degree. We should be developing independent learners and teaching them to take responsibility for their learning and production of knowledge for others.

Based on statements by both students and faculty, a discrepancy in expectations about graduate studies was evident. The faculty discussed this disconnect in expectations. Differences in statements made by faculty and students are evidenced in the following quotes. GS19 said: "I had no idea that graduate school would be so research based,” while GF2 commented:

There are others, though, who labor under a misunderstanding of what graduate study is about -- I think this is because design disciplines train undergraduates to be practitioners, so 'research' is an ambiguous and misunderstood concept. Some expect that they will continue with the same sort of coursework and projects that they did as undergraduates.

\section{Discussion}




\subsection{Implications for Educating Millennial Graduate Students}

A major finding of this study was that Millennial graduate student participants sought advanced degrees for primarily industry-related careers. This leads us to believe that graduate students and faculty may differ in their perceptions regarding motivations for seeking a graduate degree. For instance, most of the Millennial graduate students participating in this study did not see conducting empirical research as relevant to their long-term goals-even among those participants intending to pursue a Ph.D. Yet, many fashion-related master’s programs are designed to build knowledge of the research process and require a thesis project. This requirement may not be serving student expectations however, especially of students from the Millennial generation who are goal-oriented and derive motivation from those goals (Donnison 2010). The AAU (1998) recommended that graduate programs prepare students for a wide array of career options and Wender et al. asserted that graduate education should 'produce successful workers, good neighbours, good citizens, and lifelong learners’ (2010, p. 13). Consequently, while Millennial students in graduate programs should attain the capacity to critically reflect upon, apply, and make independent contributions to knowledge, graduate programs should consider creative mechanisms for teaching these skills and not hold all students accountable to conducting empirical research.

Graduate faculty need to consider whether the research component inherent in most fashion-related graduate programs is sustainable for recruitment and retention purposes. Hodges and Karpova (2010) noted that fashion programs must continually refocus their curriculum to meet industry changes. As such, an issue to address is the fundamental purpose of the master's degree and the format of the 'culminating experience.' As part of their report, Wendler et al. (2010) noted that master’s programs are increasingly evolving into 'professional programs.' 
Millennial students are obtaining master's degrees as an 'end point' and not as a stepping stone along the path to earning doctoral degrees. Additionally, Wendler et al. characterized professional master's programs as focusing on the practical application of theory as well as skills necessary for the workplace such as communication, critical thinking, and management. Given this trend, along with the finding that many Millennial graduate students intend to return to the industry after completing their master's degree, perhaps more graduate programs within the fashion-related discipline should consider developing professional master's programs based on a coursework model similar to an MBA program.

Findings of this study also suggest that faculty need to communicate more effectively the nature and rigors of graduate school, especially among those who plan to pursue a Ph.D. at the culmination of the Master's experience. Potential Millennial students need this information before choosing to begin graduate studies. When asked how they collected information on graduate programs during the application process, a majority of participants indicated that they did not visit any schools and only researched the programs online. This finding is consistent with information that suggests that Millennials tend to be motivated by speed and convenience, stopping at the first answer or solution they find. As a result, graduate program websites should clearly define the expectations of graduate school. If research is an important and emphasized component of the program, not only do department webpages need to communicate this information but the websites also need an honest explanation of what the research process entails. As noted by previous authors, Millennials rely on and trust authority to guide behaviour and make decisions (DeBard 2004, Meriac et al. 2010, Schneider and Stevenson 1999). Therefore, it is recommended that graduate faculty aid Millennials in academic and career- 
related decisions. The AAU (1998) suggested that graduate faculty should frequently evaluate students’ progress and serve as mentors throughout the students' educational experience.

Additionally, faculty need to communicate how engaging in the research process develops critical and analytical skills that are beneficial to all Millennial students completing an advanced degree, regardless of their long-term career goals. For instance, even among those who plan to work in the industry upon completion of their Master's program, having insight on how to collect and interpret data is significant to their success in their future careers. Faculty should consider methods for imparting upon all Millennial students the universal relevance of the research process.

These implications are necessary and a result of the changing student population. As Taylor notes:

Educational reform [is needed] in how we view students, how we develop learning and change related goals with and for them, how we articulate these goals to students and elicit student ownership of goals, how we engage students in their personal, developmental, lasting change, and how we assess and document these changes (2006, p. 2:50).

Once these primary issues are addressed, there then becomes a need to modify our mentoring of Millennial graduate students and teaching methods without compromising the aims of graduate education. Myers and Sadaghiani (2010) recommend counselling and interacting with Millennials with an intention to understand, rather than criticizing or becoming frustrated with Millennials because of their differences on perspectives regarding work-related tasks, approaches to education, expectations regarding supervisor-subordinate relationships, and 
decision-making abilities. This is important given Millennials' limited ability to cope when provided with constructive criticism (Donnison 2010, Howe and Strauss 2003, Taylor 2006).

Wilson and Gerber recommend appropriate strategies for teaching Millennials, including:

'(1) strive for greater clarity in course structure, assignments, and grading expectations; (2) provide significant opportunities for student initiative, participation and choice; (3) incorporate stress-reduction mechanisms; and (4) engage students in a significant, course-long conversation

on the ethical dimensions of taking a college class' (2008, p. 32). Currently, graduate courses are often loosely structured, in a seminar style format, with faculty giving a lot of academic freedom in choosing research topics, etc. However, as noted in the literature review, Millennials are unique in their characteristics of seeking regular and open communication from authority and needing continual direction and feedback (DeBard 2004, Meriac et al. 2010, Schneider and Stevenson 1999). As such, graduate faculty in the fashion discipline should review and modify their teaching and advising practices as needed, ultimately to promote the maturation and success of students representing the Millennial generation.

\subsection{Industry-Related Implications}

In promoting Millennial student success, the findings of this study also support the need to foster connections between the institution of higher learning and the fashion industry. Faculty should be engaged in developing relationships with industry professionals through networking activities such as conferences, study tours, and advisory boards. It is evident that students representing the Millennial cohort expect relevant and timely training for careers in the industry, such as learning the skills, traits, and characteristics needed for professional success. Career counselling, networking opportunities, and other such activities will offer students the experiences and training they seek. In addition to thesis projects, internships and industry-based 
practicums should also be considered as culminating experiences. Such requirements are likely to be viewed as more relevant among Millennial graduate students who seek industry positions after the master’s degree and will promote recruitment and retention efforts employed by graduate programs.

\subsection{Recommendations for Future Research}

The participants in this study were sampled from 11 different institutions. Additional data should be collected from a wider sample of graduate students and faculty from fashion programs. To increase sample size, the findings from this study can be used to create a survey to allow for more quantifiable data. This will also enable more generalizable findings to graduate programs in the fashion discipline. Future research may also wish to collect data from Master's level graduate students in programs outside of the fashion discipline. This will assist in differentiating characteristics attributed to being a Millennial versus characteristics that are specific to students in fashion programs. In a similar vein, additional research should explore similarities and differences in the motivations and expectations of Millennial students in the fashion discipline by differentiating among those in the design, merchandising, product development, historic costume, and textile science and engineering sub-disciplines (among others), as well as, among those with different chosen culminating experiences.

Further, while considerable research exists examining undergraduate teaching methods, additional information is needed on effective mentoring styles and graduate teaching methods appropriate and responsive to the characteristics of Millennial graduate students, without compromising the rigors and expectations of graduate school. Research is also needed to empirically test methods for successfully engaging Millennial graduate students in their programs of study. Teaching methods, including delivery of content, assessment of learning, 
program goals, and student learning outcomes should reflect the changing dynamics of today's Millennial graduate student population. Future research should explore the differing perceptions of Millennials among faculty of the Baby Boomer versus Generation X cohorts. As noted previously in the literature, Baby Boomers are typically more patient and understanding of Millennial students (Donnison 2010). However, as Baby Boomers near the retirement phase of their careers, graduate faculty and administrators within fashion programs will primarily be of the Generation X cohort. Fostering an understanding of Millennials and adapting graduate programs to their characteristics, work styles, and study skills, is vital to the livelihood and competitiveness of graduate studies in the fashion discipline. This research can also promote positive work relationships between Generation Xers and Millennials. This is important given Alsop’s (2008) finding that Gen Xers can be frustrated by Millennials who perceive supervisors as 'workplace parents.'

Finally, additional research should explore the expectations and experiences of professionals in the fashion industry. The information that can be drawn from this type of research will be valuable as fashion programs evaluate and refine their curricula, recruitment and retention efforts.

\section{References}

Alsop, R. 2008. The trophy kids grow up: how the Millennial generation is shaking up the workplace, New York: Jossey-Bass, Inc.

Association of American Universities. 1998. Committee on graduate education: report and recommendations.

Creswell, J. 2007. Qualitative inquiry and research design: choosing among five traditions, Thousand Oaks, CA: Sage Publications. 
DeBard, R. 2004. Millennials coming to college. New Directions for Student Services, 2004: 33-45.

Donnison, S. 2010. Unpacking the Millennials: A cautionary tale for teacher educations. Australian Journal of Teacher Education, 32: 1-13.

Hiller Connell, K. Y. and Kozar, J. M. 2011. Times they are a-changin’: identifying the motivations and expectations of the millennial-generation apparel and textiles master's degree students. Proceedings of the International Textile and Apparel Association. Available from: http://cdm16001.contentdm.oclc.org/cdm/compoundobject/collection/p16001coll5/id/411 7/rec/64 [Accessed 21 February 2013].

Hodges, N. and Karpova, E. 2010. Majoring in fashion: a theoretical framework for understanding the decision-making process. International Journal of Fashion Design, Technology and Education, 3: 67-76.

Holliday, W. and Li, Q. 2004. Understanding the Millennials: updating our knowledge about students. Reference Services Review, 32: 356-366.

Horn, L. J., Chen, X. and Chapman, C. 2003. Getting ready to pay for college: what students and their parents know about the cost of college tuition and what they are doing to find out, Washington, D.C.: National Center for Education Statistics.

Howe, N. and Strauss, W. 2003. Millennials go to college: strategies for a new generation on campus, Washington, D.C.: American Association of Collegiate Registrars and Admissions Officers.

Kowske, B. J., Rasch, R. and Wiley, J. 2010. Millennials’ (lack of) attitude problem: an 
empirical examination of generational effects on work attitudes. Journal of Business Psychology, 25: 265-279.

Levine, M. 2005. College graduates aren't ready for the real world. The Chronicle of Higher Education, 51: B11.

Lincoln, Y. and Guba, E. 1999. “Establishing trustworthiness”. In Qualitative research, $3^{\text {rd }}$ ed, Edited by Bryman, A. and Burgess, R. G. 397-444. Thousand Oaks, CA: Sage Publications.

Mackay, H. 1997. Generations: Baby Boomers, their parents and their children, Sydney: Macmillan.

Mannheim, K. 1952. Essay on the sociology of knowledge, London: Routledge \& Kegan Paul Ltd.

Martin, C. A. 2005. From high maintenance to high productivity: What managers need to know about Generation Y. Industrial and Commercial Training, 37: 39-44.

Martin, C. A. and Tulgan, B. 2001. Managing Generation Y, New Haven, CT: HRD Press.

Maxwell, J. A. 2005. Qualitative research design: an interactive approach, $2^{\text {nd }}$ ed, Thousand Oaks, CA: Sage Publications.

McGlynn, A. P. 2005. Teaching Millennials, our newest cultural cohort. The Education Digest, 71: $12-16$.

McGlynn, A. P. 2008. Millennials in college: how do we motivated them? The Education Digest, 73: 19-22.

McGuire, D., By, R. T. and Hutchings, K. 2007. Towards a model of human resource solutions for achieving intergenerational interaction in organizations. Journal of European Industrial Training, 31: 592-608. 
Meriac, J. P., Woehr, D. J. and Banister, C. 2010. Generational difference in work ethic: an examination of measurement equivalence across three cohorts. Journal of Business Psychology, 25: 315-324.

Myers, K. K. and Sadaghiani, K. 2010. Millennials in the workplace: a communication perspective on Millennials' organizational relationships and performance. Journal of Business Psychology, 25: 225-238.

Newton, F. B. 2000. The new student. About Campus, 5: 8-15.

Oblinger, D. 2003. Boomers, Gen-Xers, and Millennials: understanding the new students. EDUCAUSE Review, 38: 37-47.

Ott, B., Blacksmith, N. and Royal, N. 2008, March 13. What generation gap? Job seekers for different generations often look for the same things from prospective employers, according to recent Gallup research, http://gmp.gallup.com.

Pekala, N. 2001. Conquering the generational divide. Journal of Property Management, 66: 30-38.

Sax, L. J. 2003. Our incoming students: what are they like? About Campus, 8: 15-30.

Schiffman, L. and Kanuk, L. 2010. Consumer behaviour, $10^{\text {th }}$ ed, New York: Prentice Hall.

Schneider, B. and Stevenson, D. 1999. The ambitious generation: America's teenagers motivated but directionless, New Haven, CT: Yale University Press.

Schuman, H. and Scott, J. 1989. Generations and collective memories. American sociological review, 54: 359-381.

Smith, J. A., Flowers, P. and Larkin, M. 2009. Interpretative phenomenological analysis, Thousand Oaks, CA: Sage Publications.

Strauss, W. and Howe, N. 2000. Millennials rising: the next great generation, New York: 
Vintage Books.

Taylor, M. L. 2006. “Generation NeXt comes to college: 2006 updates and emerging issues”. In A collection of papers on self-study and institutional improvement, Edited by: Van Kollenburg, S. E. 48-55. Chicago, IL: Higher Learning Commission of the North Central Association of Colleges and Schools.

Twenge, J. M., Konrath, S., Foster, J. D., Campbell, W. K. and Bushman, B. J. 2008. Egos inflating over time: a cross-temporal meta-analysis of the Narcissistic Personality Inventory. Journal of Personality, 76: 903-917.

Wendler, C., Bridgeman, B., Cline, F., Millett, C., Rock, J., Bell, N. and McAllister, P. 2010. The path forward: the future of graduate education in the United States, Princeton, NJ: Educational Testing Service.

Wilson, M. and Gerber, L. E. 2008. How generational theory can improve teaching: strategies for working with the “millennials.” Currents, 1: 29-44. 
Table 1. Demographic information for graduate student participants.

\begin{tabular}{|c|c|c|c|c|c|c|}
\hline ID & Sex & Age & $\begin{array}{l}\text { Student's culminating } \\
\text { experience }\end{array}$ & $\begin{array}{l}\text { Plans after } \\
\text { Master’s degree }\end{array}$ & Undergraduate major & $\begin{array}{l}\text { Degrees offered at } \\
\text { institution }\end{array}$ \\
\hline GS1 & Female & 21 & Thesis & Industry & Fashion & $\mathrm{PhD}, \mathrm{MS}$ \\
\hline GS2 & Female & 22 & Thesis & $\mathrm{PhD}$ & Fashion & $\mathrm{PhD}, \mathrm{MS}$ \\
\hline GS3 & Female & 22 & Thesis & Industry & Accounting & MS \\
\hline GS4 & Female & 23 & Thesis & $\mathrm{PhD}$ & Fashion & $\mathrm{PhD}, \mathrm{MS}$ \\
\hline GS5 & Female & 23 & Thesis & Industry & Fashion & MS \\
\hline GS6 & Female & 23 & Course work only & $\mathrm{PhD}$ & Fashion & $\mathrm{PhD}, \mathrm{MS}, \mathrm{MA}$ \\
\hline GS7 & Female & 24 & Thesis & $\mathrm{PhD}$ & Fashion & MS \\
\hline GS8 & Female & 24 & Thesis & $\mathrm{PhD}$ & Fashion & $\mathrm{PhD}, \mathrm{MS}$ \\
\hline GS9 & Female & 24 & Thesis & Industry & Business & MS \\
\hline GS10 & Female & 24 & Thesis & Industry & Fashion & $\mathrm{PhD}, \mathrm{MS}$ \\
\hline GS11 & Female & 25 & Thesis & Industry & History & $\mathrm{PhD}, \mathrm{MS}, \mathrm{MA}$ \\
\hline GS12 & Female & 25 & Thesis & Industry & Fibre Chemistry & $\mathrm{PhD}, \mathrm{MS}, \mathrm{MA}$ \\
\hline GS13 & Male & 25 & Thesis & $\mathrm{PhD}$ & Fashion & $\mathrm{PhD}, \mathrm{MS}, \mathrm{MA}$ \\
\hline GS14 & Female & 25 & Course work only & Industry & Psychology & $\mathrm{PhD}, \mathrm{MS}$ \\
\hline GS15 & Male & 25 & Course work only & Industry & Fashion & MS \\
\hline GS16 & Female & 25 & Thesis & Industry & Fashion & MS \\
\hline GS17 & Female & 25 & Course work only & Industry & Fashion & $\mathrm{PhD}, \mathrm{MS}$ \\
\hline GS18 & Female & 25 & Thesis & $\mathrm{PhD}$ & Fashion & unknown \\
\hline GS19 & Female & 26 & Thesis & Industry & Fashion & $\mathrm{MA}$ \\
\hline GS20 & Female & 26 & Thesis & $\mathrm{PhD}$ & Fashion & MS \\
\hline GS21 & Female & 27 & Thesis & Industry & Fashion & MA \\
\hline GS22 & Female & 28 & Thesis & Industry & Fashion & PhD, MS \\
\hline GS23 & Female & 29 & Design project & $\mathrm{PhD}$ & FCS Education & $\mathrm{PhD}, \mathrm{MS}, \mathrm{MA}$ \\
\hline GS24 & Female & 30 & Thesis & $\mathrm{PhD}$ & Fashion & $\mathrm{PhD}, \mathrm{MS}$ \\
\hline GS25 & Male & 30 & Course work only & Industry & Labour Economics & $\mathrm{PhD}, \mathrm{MS}, \mathrm{MA}$ \\
\hline GS26 & Female & 32 & Thesis & Industry & Fashion & $\mathrm{PhD}, \mathrm{MS}$ \\
\hline
\end{tabular}


